\title{
Helpers, Construction Trades
}

National Cancer Institute

\section{Source}

National Cancer Institute. Helpers, Construction Trades. NCI Thesaurus. Code C122467.

Workers who perform basic tasks that require physical labor on construction sites. 